Volume 11

Issue 1 Information and Communications

Technologies in Mass Atrocities Research and

Article 15

Response

$5-2017$

\title{
Book Review: The Magnitude of Genocide
}

Jonathan Leader Maynard

University of Oxford

Follow this and additional works at: https://digitalcommons.usf.edu/gsp

\section{Recommended Citation}

Leader Maynard, Jonathan (2017) "Book Review: The Magnitude of Genocide," Genocide Studies and Prevention: An International Journal: Vol. 11: Iss. 1: 115-118.

DOI:

http://doi.org/10.5038/1911-9933.11.1.1471

Available at: https://digitalcommons.usf.edu/gsp/vol11/iss1/15

This Book Review is brought to you for free and open access by the Open Access Journals at Digital Commons @ University of South Florida. It has been accepted for inclusion in Genocide Studies and Prevention: An International Journal by an authorized editor of Digital Commons @ University of South Florida. For more information, please contact digitalcommons@usf.edu. 
Book Review: The Magnitude of Genocide

Jonathan Leader Maynard

University of Oxford

Oxford, United Kingdom

The Magnitude of Genocide

Colin Tatz and Winton Higgins

Santa Barbara, Praeger, 2016

296 Pages; Price: $\$ 63.00$ Hardcover

Reviewed by Jonathan Leader Maynard

University of Oxford

Given that genocide studies is no longer a field in its infancy, it has generated surprisingly few overarching introductions to its subject matter. ${ }^{1}$ This is one reason to welcome Colin Tatz's and Winton Higgins's new volume, The Magnitude of Genocide, in which the authors seek to produce a comprehensive framework for understanding how genocide should be conceptualized and explained, illustrated by presentations of a wide range of historical and recent cases. Their project is organised into four parts: first, a discussion of the definition of genocide and the evolution of its practice from premodern to modern times; second, a lengthy five chapter analysis of "genocide at work" - the causal dynamics involved in producing genocide and determining the character of particular cases, as well as rescues and interventions; third, an analysis of the contrasting ways states behave in the aftermath of genocide; and finally, a consideration of the trends of genocide into the future, and the prospects for its prevention.

There is much to commend here. The Magnitude of Genocide is impressive for its historical and geographical reach. Whilst "classic cases" such as the Holocaust and Armenian Genocide recur with some frequency, Tatz and Higgins make a much more sustained effort than most to bring a broader universe of genocides to the reader's attention. Alongside a plethora of premodern cases, the authors give attention to violence in Burundi, Rwanda, Mao's China, Darfur, the Nuba Mountains, Bangladesh, East Timor, Liberia, Cambodia, the Ukrainian Holodomor and the wars in Yugoslavia, plus colonial rule in Canada, Australia, German South West Africa, the Congo, and Ireland, as well as recent atrocities by Daesh. Tatz and Higgins' extensive consideration of cases perpetrated by Western democracies or their colonies, alongside those of more obviously vicious regimes, is particularly welcome, and the general empirical breadth supports the authors' analysis of genocide throughout the book. However, its strongest sections - perhaps reflecting the balance of their past work-offer impressive analyses of the contrasting ways groups and organizations respond to genocide. Chapter 8 provides an excellent comparative discussion of several cases of rescue, resistance, and intervention, contrasting these with cases of inaction, passivity, and bystanderism by states and non-state actors. Two lucid chapters follow on "Denialism" and "Punishment and Impunity" - the latter (bar a slightly dismissive critique of reconciliation efforts in South Africa), provides a particularly informative overview of successes and failures in efforts to create an effective punitive regime for genocide.

These are all real strengths, but this is an uneven book with some significant weaknesses. For a start, whilst the prologue and opening chapter emphasize that the book "offers neither a compendium nor an encyclopaedia of genocide," Tatz and Higgins are strangely vague on what this book does seek to contribute, beyond the very general claim to "present a framework of concepts and ideas for a better understanding of the nature and place of genocide in human history." 2 At least two more contributions are implied but remain elusive. First, Tatz and Higgins repeatedly express

\footnotetext{
${ }^{1}$ Two notable exceptions are: Adam Jones, Genocide: A Comprehensive Introduction, $2^{\text {nd }}$ ed. (New York: Routledge, 2010); Scott Straus, Fundamentals of Genocide and Mass Atrocity Prevention (Washington D.C.: United States Holocaust Memorial Museum, 2016).

${ }^{2}$ Colin Tatz and Winton Higgins, The Magnitude of Genocide (Santa Barbara: Praeger, 2016), 15.
} 
the hope that their book will help efforts to prevent genocide's recurrence. Perhaps any book that generally helps people understand genocide supports this objective indirectly, but The Magnitude of Genocide makes few more concrete contributions to genocide prevention. Its valuable comparative analysis of past cases of rescue and intervention is, unfortunately, not used as a basis for any detailed prescriptive conclusions. The one section which does consider future prevention, in the last few pages of the book's closing chapter, is esoteric: Tatz and Higgins briefly declare the need to wage a conventional ground war against Daesh before, in a section awkwardly titled "Genocide studies segues into a civics masterclass," suggesting that the future prevention of genocide requires a restoration of republican civic democracy in the West. This is not an uninteresting idea, but with a compressed exegesis in barely four pages it seems to reflect the authors' desire to digress on the problems facing contemporary democratic politics more than a serious examination of genocide prevention. Regrettably, there is little consideration of the specific challenges that presently vex preventive efforts in practice.

The second elusive project of the book is more puzzling. The prologue and opening chapter raise an argument that is, presumably, the source of the book's title: Tatz and Higgins suggest that "a metaphorical rather than literal Richter scale" for the magnitude of genocide should be developed, since "genocide studies needs to find common ground on terminology, and yardsticks with which to assess degrees and gradations of the crime." ${ }^{3}$ This is an interesting albeit controversial claimTatz and Higgins acknowledge the need to avoid a rather gaudy "league table of horror." ${ }^{4}$ Strangely, however, this argument then seems to disappear from the book until its very last page. Here, Tatz and Higgins abruptly state that whilst they "don't advocate a logarithmic or arithmetical scale of immensity and intensity...the resort to even a rough categorization of genocides into genocide 1 , 2,3 and 4 would help to distinguish between often dissimilar genocides." ${ }^{\prime 5}$ This is the first time such a typology is mentioned and Tatz and Higgins provide no further explanation regarding what these different numbers would denote. It is a peculiar and confusing trajectory for the book's eponymous theme.

More generally, Magnitude of Genocide often leaves its more original and provocative ideas undercooked. Early mention is made of Tatz's concept of the "doctorhood of genocide" - the ideologues, professionals, and technocrats who provide the quasi-scientific intellectual backdrop to genocidal practices. But this idea is not developed in detail, and whilst it is used to set up a descriptive discussion of the professions generally involved in genocides, ${ }^{6}$ Tatz and Higgins do not explain how this significantly advances understanding of why they occur. And whilst their associated claim that "too little research has focused on the occupational status of the major actors involved"7 may be correct, it is undermined by the authors' neglect of several recent works which do seem to operate in this area (Michael Thad Allen's The Business of Genocide seems particularly notable by its absence). Another interesting suggestion is that the "gestation process" behind genocide is better understood as a "sequence of discursive shifts" 8 rather than-à la Gregory Stanton's Ten Stages of Genocide-a "model of discrete stages." Again, however, Tatz and Higgins do not explain why a model of discursive shifts is superior, instead spending most of their single page discussion simply outlining Stanton's sequence and their own. There is also no consideration of the main problem with schemas of this type - that they imply a singular and linear pathway to genocide, when most contemporary scholarship would emphasis dynamic processes and equifinality.

Ultimately, The Magnitude of Genocide is weakest in its attempt-largely in Part II-to convincingly synthesize causal explanations of genocide. Again, Tatz and Higgins marshal an impressive range of explanatory themes from existing scholarship, but these are haphazardly

\footnotetext{
${ }^{3}$ Ibid., xiii.

${ }^{4}$ Ibid., 7.

${ }^{5}$ Ibid., 249.

${ }^{6}$ Ibid., 114 -122.

${ }^{7}$ Ibid., 114.

${ }^{8}$ Ibid., 113.
} 
connected, and the two most prominent analytical devices deployed are not entirely convincing. First, Tatz and Higgins devote chapter 4 in its entirety to "The Race Factor," suggesting that "race and racism are the common denominators in modern genocidal history." ${ }^{\prime \prime}$ Given their very broad conception of racism - "all practices that arise from a labelling and stereotyping that inevitably carries with it undesirable (and intractable) social characteristics"10 - this strong explanatory prioritization of race may be defensible, and it is followed by some typically clear and illustrative consideration of specific cases. But this chapter is problematically untethered from much leading research on race, ethnicity, and mass violence-Tatz and Higgins make no mention of the extensive quantitative literature which finds weak correlations between ethnic fractionalization and mass atrocities, nor do they get to grips with the paradoxical picture that emerges from studies of the identity-mobilization that does occur. Briefly: genocide involves killing along lines of identity, yet it is increasingly clear that the identities and associated prejudices involved often appear to be weakly internalized by many perpetrators of genocide and their supporting populations. Modern scholarship has therefore gained considerable sophistication by studying the conditions under which such identities can be politically "activated," the complicated and interactive way in which those identities are constructed and negotiated (including the way they undergo critical changes during violence), and the specific and diverse causal mechanisms through which mobilisation of identity is actually implicated in practices of killing. ${ }^{11}$ This is largely absent from Tatz's and Higgins's analysis of race, which therefore seems theoretically thin and not up to speed with contemporary thinking. Indeed, the authors are surprisingly willing to aver explanatory force to "ancient hatreds," 12 despite the intense criticism this notion has received from most contemporary scholars.

The second major analytical theme Tatz and Higgins use to account for modern genocides is modernity itself. Again, this is familiar terrain for genocide studies, but the core of their argument rests on a rendition of liberal modernization theory that seems excessively crude. In the various available "routes" states can take to develop, Tatz and Higgins argue, "the liberal-democratic route leads to the most thoroughgoing modernization of civil society and the state, and can be achieved under relatively humane conditions." ${ }^{13}$ By contrast, genocide - at least in Germany - was rooted in "the failure of the 'bourgeois revolutions' in the German sovereign states [that] blocked this kind of benign development and condemned them to the reactionary route into the modern world." ${ }^{14}$ Parts of this argument are clearly plausible: democracy, a vibrant civil society and other associated liberal institutions can function as important restraints on genocide. But this does not mean that "proper" modernization can simply be identified with liberalism, and non-liberal orders treated as backward or reactionary deviations from history's proper course. Indeed, such an account of modernization generates considerable tensions within Tatz' and Higgins' own arguments. If a reactionary path to modernity is a precondition of modern genocides, why are liberal states apparently capable of committing them (and, certainly, capable of other forms of mass killing)? How can Tatz and Higgins claim, within a page of arguing that Germany's "reactionary modernization" explains the preconditions of the Holocaust, that "the German precedent warns us that [processes leading to genocide] can overtake any Western country" ${ }^{15}$ Or, if this "failed modernization" process is unique to the Holocaust, how can the Holocaust be the paradigm case from which we should

\footnotetext{
${ }^{9}$ Ibid., 51.

${ }^{10}$ Ibid., 51.

${ }^{11}$ For example: Sarah Davies, "'Us Against Them': Social Identity in Soviet Russia, 1934-41," in Stalinism: New Directions, ed. Sheila Fitzpatrick (London: Routledge, 2000); Ronald Grigory Suny, "Why We Hate You: The Passions of National Identity and Ethnic Violence," Berkeley Program in Soviet and Post-Soviet Studies Working Paper Series (2004); Michael Mann, The Dark Side of Democracy: Explaining Ethnic Cleansing (Cambridge, UK: Cambridge University Press, 2005); Siniša Malešević, Identity as ideology: understanding ethnicity and nationalism (Basingstoke: Palgrave Macmillan, 2006); Scott Straus, Making and Unmaking Nations: War, Leadership and Genocide in Modern Africa (Ithaca: Cornell University Press, 2015).

${ }^{12}$ For example: Tatz and Higgins, The Magnitude of Genocide, 5, 84, 91, 99, 111.

${ }^{13}$ Ibid., 71.

${ }^{14}$ Ibid., 72.

${ }^{15}$ Ibid., 74 .
} 
develop generalizable theories of genocide? ${ }^{16}$ To maintain the picture of a dysfunctional protomodern German state, Tatz and Higgins are also led to some implausible empirical claims, such as the assertion that in World War I and II, Germany started two wars it was "bound to lose" and was dragged to defeat by an inevitable "Montesquieuian logic." This hardly matches most military histories of either conflict. Not all Tatz' and Higgins' observations on modernization are so awry, but the overall theoretical synthesis seems dubious.

This all imposes limits on how convincing Magnitude of Genocide is as an explanatory framework for the causes of genocide. Its' most intriguing ideas need development, its empirical breadth matched by greater depth, and a broader range of major recent scholarship bearing on causal questions better integrated. These flaws, however, are not fatal to the book's value. Several sections will be appreciated by students and scholars for their elegant introductions to the many elements of the historical record of genocide. Tatz and Higgins valuably clarify the contrasting ways states respond to genocide. And their volume sets high standards in its accessibility, the scope of its comparative analysis, and its balanced consideration of the history of genocide that future work would do well to emulate.

${ }^{16}$ Ibid., 70 . 